\title{
Molecular and morphological analyses confirm two new species of the Hydraena emarginata-saga clade (Coleoptera, Hydraenidae) from Spain and France
}

\author{
MARCO TRIZZINO ${ }^{1}$, MANFRED A. JÄCH ${ }^{2}$, PAOLO AUDISIO $^{1} \&$ IGNACIO RIBERA $^{3,4}$
}

1 Sapienza Rome University, Italy

2 Naturhistorisches Museum Wien, Austria

3 Museo Nacional de Ciencias Naturales (CSIC), Madrid, Spain

4 Institute of Evolutionary Biology (CSIC-UPF), Barcelona, Spain

E-mails:marco.trizzino@uniroma1.it;manfred.jaech@nhm-wien.ac.at; paolo.audisio@uniromal.it; ignacio.ribera@ibe.upf-csic.es

*Correspondence: Marco Trizzino, Sapienza Rome University, Department of Biology and Biotechnologies "C. Darwin“, via A. Borelli 50, I-00161 Rome, Italy. E-mail: marco.trizzino@uniroma1.it

\begin{abstract}
Basing on morphological and molecular analyses, the existence of two undescribed species, $H$. diazi from north-eastern Spain and French Pyrenees, and H. fosterorum from north-central Spain is herein confirmed.These species are members of an European endemic complex of hydraenid beetles, the Hydraena emarginata-saga clade, belonging to the "Haenydra" lineage. The two new species are described and the geographic range of the widespread $H$. saga is revised.
\end{abstract}

Key words: "Haenydra“, new species, W Europe, mtDNA.

\section{Introduction}

Hydraena Kugelann, with more than 850 species worldwide, is the most speciose genus within the family Hydraenidae and certainly one of the most speciose genera among aquatic Coleoptera. Within this genus, Jäch et al. (2000) recognized some monophyletic derived species groups, defined as "lineages". Among them, the "Haenydra" lineage (or H. gracilis species group) includes more than 85 species distributed exclusively in the western Palaearctic from Ireland and Portugal to the Urals and Iran (Jäch 2004; Audisio et al. 2009).

The monophyly of the "Haenydra" lineage is supported, among other characters, by the absence of parameres in the aedeagus (Jäch et al. 2000) and by a combination of mitochondrial and nuclear genes (Ribera et al. in press). Within the lineage, several species clades can be identified on the base of external morphology and aedeagal characters. One of these is the Hydraena emarginata-saga clade, which includes at least six described sibling species: H. emarginata Rey, from northern Spain and the French Pyrenees, H. hispanica Ganglbauer, from the Iberian Peninsula, H. larissae Jäch and Díaz and H. tarvisina Ferro from northern Italy, $H$. alpicola Pretner from the eastern Alps, and finally $H$. saga Orchymont thought to be widely distributed from Spain to the Ukraine. Other species, such as $H$. samnitica Fiori from central Italy, $H$. pangaei Jäch from north-eastern Greece, $H$. pelops Jäch from the Peloponnese, $H$. dalmatina Ganglbauer from the Balkans, and the widely distributed $H$. belgica Orchymont (Belgium to Romania) were thought to be less closely related to the $H$. emarginata-saga clade from a morphological standpoint. However, molecular data (see 
below) suggest closer affinities within this cluster of species, despite of their marked morphological diversification.

Hydraena saga was described by Orchymont (1930) from Germany, near Bonn. A preliminary molecular analyses confirmed that the Iberian/Pyrenean populations were in fact not directly related to the eastern populations of $H$. saga (Ribera et al. in press). Subsequent morphological examination of material of Hydraena saga s.l. from Austria, Bosnia, Czech Republic, France, Hungary, Montenegro, Poland, Romania, Serbia, Slovakia, Spain and Ukraine confirmed these differences and further revealed that the populations from Spain and France in fact represent two new species, which are described below. We also include a preliminary molecular phylogeny of the $H$. emarginata-saga clade to better understand the relationships among the studied species.

\section{Acronyms}

BMNH: The Natural History Museum, London, UK.

CSR: Zoological Collection, Dipartimento di Biologia e Biotecnologie "C. Darwin“, Sapienza Università di Roma, Italy.

IBE: Institut de Biología Evolutiva (UPF-CSIC), DNA\&Tissue collection, Barcelona, Spain. JFL: Javier Fresneda Collection, Llesp, Spain

MNCN: Museo Nacional de Ciencias Naturales (CSIC), Madrid, Spain.

NMW: Naturhistorisches Museum Wien, Austria.

\section{Material and methods}

Taxon sampling, DNA extraction and sequencing

Molecular methods follow the procedure outlined in Ribera et al. (in press). Specimens were preserved in absolute ethanol in the field (Table 1). Extractions of single specimens were non-destructive, using a standard phenol-chloroform method or commercial column kits. Vouchers and DNA samples are kept in the collections of the MNCN, IBE and CSR. We included all specimens of the " $H$. gracilis lineage" studied in Ribera et al. (in press), plus additional specimens of the two new species, two specimens of $H$. saga from Austria (considered to be the true $H$. saga), and examples of $H$. pangaei and $H$. samnitica (Table 1 ). Trees were rooted in the species pair $H$. sinope and H. septemlacuum, according to the results of Ribera et al. (in press). We amplified fragments of four mitochondrial genes: 3 ' end of coxl; 3' end of rrnL; full trnL and 5' end of nadl (see Ribera et al. in press for primers and other details). Variation in the nuclear genes SSU and LSU among the species of the $H$. gracilis lineage was minimal and not informative, so these genes were not included. New sequences have been deposited in GenBank (NCBI) with Accession Numbers displayed in Table 1.

\section{Phylogenetic analyses}

Bayesian analyses were conducted on a combined data matrix with MrBayes 3.1.2 (Huelsenbeck \& Ronquist 2001), which runs two independent, simultaneous analyses, using two partitions corresponding to the cox 1 and $r r n L+t r n L+n a d 1$ fragments with evolutionary models estimated with jModeltest (Posada 2008). MrBayes ran for $10^{\wedge} 6$ generations using default values, saving trees at each 500 generations. "Burn-in" values were established after visual examination of a plot of the standard deviation of the split frequencies between two simultaneous runs. We also used Maximum Likelihood as implemented in the on-line version of RAxML (which includes an estimation of bootstrap node support, Stamatakis et 
al. 2008), using GTR $+\mathrm{G}$ as the evolutionary model and the same gene partitions used in MrBayes.

Material of Hydraena saga examined:

1 male and 2 females Czech Rep. or Germany, Böhmerwald, Eisenstein (NMW); 1 male Upper Austria, Mühlviertel, Reichenau (NMW); 1 male, Poland, Srebrna Góra (NMW); 2 males Czech Rep., Kaplice (NMW); 2 males and 3 females Czech Rep., "Mährisch Weißkirchen" [Hranice] (NMW); 1 male Czech Rep., "Hof" [Dvorce] (NMW); 2 males Czech Rep., "Aussee" [Úsov] (NMW); 1 male and 5 females Czech Rep., Beskids (NMW); 2 females Lower Austria, Merkersdorf, Kajabach (NMW); 1 male Lower Austria, Stiefernbach (NMW); 3 males and 3 females Lower Austria, Retzbach (NMW); 6 males and 10 females Slovakia, Muran (NMW, CSR); 2 males Slovakia, Nizke Tatry Mountains, Poltica river (IBE, MNCN, DNA voucher numbers MNCN-AI358 and MNCN-AI485); 1 male and two females Hungary, Aggtelek N.P., Szögliget (NMW); 1 male Hungary, Bükk Mountains, Nagyvisnyo (NMW); 1 male Hungary, Gyertyanliget (NMW); 1 male and two females Hungary, Pálháza (NMW); 1 male Hungary, Körmöcbáuya (NMW); 1 female Hungary, Szklenófürdö (NMW); 1 male Csík Mountains, Kászon (NMW); 1 male Bosnia, Patkovina (NMW); 1 female Bosnia, Prevrač (NMW), 2 males and 2 females Bosnia, Višegrad (CSR); 4 females Montenegro, Kolašin Pčinja (NMW); 1 male Romania, Máramaros (NMW); 1 male Romania, Transylvania, Caraş-Severin, Sasca Montana (NMW); 2 males and 2 females Romania, Sinaia, Cumpatu (NMW); 1 female Serbia, Kućište (NMW); 2 males Ukraine, Worochta (NMW).

Hydraena diazi n. sp. Trizzino, Jäch \& Ribera

(Figs 1-4)

Type locality: Spain, Barcelona province, Montseny, La Costa, Sot de Ritronyes, $620 \mathrm{~m}$, $\mathrm{N} 41^{\circ} 45^{\prime} 23.5^{\prime \prime} \mathrm{E} 2^{\circ} 24^{\prime} 49.8^{\prime \prime}$

Type material: Holotype male (MNCN): "ES Barcelona, Montseny 10.9.2006 / La Costa de M.: Sot de Ritronyes / 620m N414'23.5” E 2²4'49.8" /Ribera, Hernando \& Aguilera leg.". Paratypes (58 specimens: CSR, IBE, MNCN, NMW): 6 males and 10 females same locality and data than holotype; one of the males used for DNA extraction and sequencing, voucher number MNCN-AI479. 2 males and 4 females Spain, Barcelona province, Montseny, Santa Fe del Montseny, road Turo del Home to Sot de Bernadal, $1134 \mathrm{~m}$ a.s.l., N41 $45^{\prime} 45.2^{\prime \prime}$ E2²6"55.0", 23.7.2005, Ribera leg. 2 males Spain, Guipuzkoa province, Oiartzun, $240 \mathrm{~m}$ a.s.1.; N43 ${ }^{\circ} 16^{\prime} 10.2^{\prime \prime} \mathrm{W} 01^{\circ} 48^{\prime} 20.5^{\prime}$ ', 16.7.2006, Ribera \& Cieslak leg.; one used for DNA extraction and sequencing, voucher number MNCN-AI1011. 1 male and 1 female Spain, Girona province, Meranges, Fontanera, torrent de la Mata de 1'Os, Ribera \& Aguilera leg. 10.6.1995. 1 male Spain, Barcelona, Bagà, Riera de Gréixer, N38²'52.4" E02 59'18.5", 1000 m, 22.6.1994, Fresneda leg. 5 males and 8 females Spain, Barcelona, Mosqueroles, Riera Ciuret, N41 ${ }^{\circ} 43^{\prime} 50.5^{\prime \prime}$ E02 $26^{\prime} 04.2^{\prime \prime}, 440 \mathrm{~m}, 20.3 .1989$, Fresneda leg. 1 male and 4 females Spain, Barcelona, Mosqueroles, Riera Ciuret, N37²6'20.5" E0321'34.8", 440 m, 23.3.1989, Fresneda leg. 1 male Spain, Vizcaya, Villaro, Río Arratia, N38 $55^{\prime} 45.9$ E034'35.9", 140 m, 5.6.1985, Rico leg. 1 male and 6 females Spain, Lleida, Salardú-Naut Aran, Montgarri, N38 $35^{\prime} 49.2^{\prime \prime}$ E02 $27^{\prime} 49.7^{\prime \prime}, 1650$ m, 15.10.1985, Fresneda leg. 1 female Spain, Lleida, Salardú-Naut Aran, Montgarri, N38³5'49.2" E02²7'49.7", $1650 \mathrm{~m}$, 
11.5.1986, Fresneda leg. 2 males and 2 females Spain, Lleida, Vielha-Mig Aran, Boca nord túnel de Vielha, N38³1'26.2" E02²0'41.7", 1510 m, 2.4.1989, Fresneda leg.

Additional material: 1 male France, Eastern Pyrenees, Les Angles; 1 male and 1 female France, Eastern Pyrenees, Larrau. 1 male France, Eastern Pyrenees, Suchon. 1 male France, Eastern Pyrenees, Gabas. 2 males Spain, Catalonia, Lleida.

Description: 2.2-2.4 mm long. Head, pronotum and elytra dark brown to black, distal third of elytra in some specimens dark reddish brown to paler reddish brown. Palpi and legs paler reddish brown.

Head: labrum with V-shaped notch anteriorly (but not as deep as in e.g. Hydraena larissae). Fronto-clypeal suture slightly arcuate, not strongly impressed. Middle of frons moderately densely punctate, lateral portion of frons very densely punctate, as in related species. Occipital ridge well developed. Eyes moderately large, maxillari palpi very long, about twice as long as distance between eyes.

Pronotum wider than long, moderately cordiform, anterior margin concave, anterior angles more or less rounded. Lateral margin slightly denticulate. Disc slightly more convex than in Hydraena larissae, rather densely punctate near anterior and posterior margins, along midline and around posterior fovae. Fovae hardly impressed.

Elytra elongate, parallel-sided, rather strongly declivous laterally. Nine rows of punctures between suture and shoulder. Strial punctures moderately large, slightly more deeply impressed than in H. saga and H. larissae. Explanate margin of elytra moderately wide, as in all members of the $H$. emarginata-saga complex.

Mentum and submentum microreticulate. Posterior genal ridge not particularly prominent, mostly glabrous. Prosternum with indistict median keel. Angles between mesosternal disc and mesosternal process small as in e.g. H. larissae and H. saga. Metaventral plaques well developed, divergent posteriorly. Glabrous areas behind metacoxal sockets not very pronounced; abdominal ventrites III-VI more or less entirely covered with hydrofuge pubescence, abdominal ventrites VII and VIII largely glabrous, as in related species.

Aedeagus (Fig. 1): Length of main piece $572 \mu \mathrm{m}$ (holotype), with four setae, three on left side and one very reduced (typical of members of the $H$. emarginata-saga group) on right side. Apex distinctly more rounded than in $H$. saga and H. alpicola (Figs 9, 10); a peculiar and clearly visible small $\mathrm{V}$-shaped incision on pre-apical dorsal side of main piece. Distal half of main piece in right side view markedly more curved and wider (about 1.3 times) than in $H$. saga. Pre-basal tooth not very prominent, phallobase symmetrical in ventral view. Distal lobe as in $H$. saga and $H$. alpicola, seemingly without variability in size.

Gonocoxite and female tergite $\mathrm{X}$ as in Figs 2-3.

Secondary sexual characters: male elytral apices conjointly rounded, with very small sutural notch. Female elytral apices slightly conjointly rounded (Fig. 4), with a more or less large sutural notch. Female ventrites V and VI with fringe of long setae. Male ventrite VI enlarged. Male mesotibia with a row of ca. eight minute denticles along mesial face of posterior half. Male metatibia with fringe of long setae along mesial face of posterior half. Male tergite $\mathrm{X}$ as in $H$. saga and related species.

Differential diagnosis: $H$. diazi is clearly related to $H$. saga, $H$. larissae, $H$. emarginata, $H$. alpicola, and especially to the second new species described in this paper (see below). The aedeagus of $H$. diazi (Fig. 1) could be easily distinguished from the other related species by the markedly curved and wide apical half of the main piece and by the peculiar distal apex of 
the main piece. The aedeagus of $H$. emarginata (Fig. 11) can be distinguished also by its distinctly larger size (PL: 610-665 $\mu \mathrm{m}$ ), and by the distinctly larger distal lobe.

Distribution: $H$. diazi has a typical Pyrenean distribution, occurring in the southern (Spanish) and in the northern (French) side, and extending to some mountain massifs in Catalonia. All Pyrenean specimens previously attributed to $H$. saga almost certainly belong to $H$. diazi.

Etymology: We are pleased to dedicate this species to our dear friend and collegue Juan Angel Díaz (University of Santiago de Compostela, Spain).

Hydraena fosterorum n. sp. Trizzino, Jäch \& Ribera

(Figs 5-8)

Type locality: Spain, Burgos province, Fresneda de la Sierra, Tirón river, $1085 \mathrm{~m}$ a.s.1., N42 16 '46.2" W3 $3^{\circ}$ '56.0".

Type material: Holotype male (MNCN): "ES Burgos 22.10.2004 / Fresneda de la Sierra: r. Tirón / N42¹6'46.2" W37'56.0" / 1085m I.Ribera leg.". Paratypes (129 specimens: BMNH, CSR, IBE, MNCN, NMW): 8 males and 4 females same locality and data than holotype; one male used for DNA extraction and sequencing, voucher number MNCN-AI282. 4 males and 8 females Spain, La Rioja province, Logroño, Posadas, Río Oja, $1159 \mathrm{~m}$, N42 ${ }^{\circ} 12^{\prime} 36.0^{\prime \prime}$ W3 4'27.8" 23.10.04 Ribera leg.; one male used for DNA extraction and sequencing, voucher number MNCN-AI481. 8 males and 5 females Spain, La Rioja province, Logroño, Posadas, Río Oja, artificial pool, $1200 \mathrm{~m}$, N42²12’36.0” W34’27.8” 23.10.04 Ribera leg. 33 males and 52 females Spain, Burgos, Fresneda de la Sierra Tirón, Río Tirón, N42 ${ }^{\circ} 16^{\prime} 46.2^{\prime \prime} \mathrm{W}^{\circ} 7^{\prime} 56.0^{\prime \prime}, 1100 \mathrm{~m}, 15.8 .1994$, Fresneda leg. 1 male Spain, Soria, Vinuesa, $2 \mathrm{~km}$ Pto. Sta. Inés, 16.7.1991, Fery leg. 1 female Spain, Soria, Vinuesa, Laguna Negra, 13.6.1990, Fresneda leg. 3 males and 1 females Spain, Zaragoza, Moncayo, Fuente del Pedregal, 9.4.1993, Fresneda leg. 1 female Spain, Zaragoza, Moncayo, entre Veruela y Na. Sierra Del Moncayo, 9.4.1993, Fresneda leg.

Description: $2.15-2.30 \mathrm{~mm}$ long. Male habitus as in Hydraena diazi.

Aedeagus (Fig. 5): Length of main piece $555 \mu \mathrm{m}$, with four setae, three on left side and one very reduced (typical of members of the $H$. emarginata-saga complex) on right side. Apex distinctly more rounded than in related species (including $H$. diazi); pre-apical dorsal incision absent. Apical half of the main piece in right side view markedly more curved and wider (about 1.3 times) than in $H$. saga and $H$. alpicola (Figs 5, 9, 10).

Pre-basal tooth not very prominent, phallobase symmetrical in ventral view.

Distal lobe as in $H$. saga and $H$. alpicola, seemingly without variability in size.

Female gonocoxite and tergite $\mathrm{X}$ as in Figs 6-7.

Secondary sexual characters: male elytral apices conjointly rounded, with a small sutural notch. Distal third of female elytral apices very widely explanate (Fig. 8), conjointly rounded, with a very large sutural notch (resembling $H$. samnitica and $H$. pangaei). Female ventrites V and VI with fringe of long setae. Male ventrite VI enlarged. Male mesotibia with a row of ca. eight minute denticles along mesial face of posterior half. Male metatibia with fringe of long setae along mesial face of posterior half. Male tergite X as in H. saga and related species. 
Differential diagnosis: $H$. fosterorum is cleary related to $H$. diazi, $H$. saga, $H$. larissae, $H$. emarginata, and $H$. alpicola. The aedeagus of $H$. fosterorum (Fig. 5) could be easily distinguished from the other related species by the markedly curved and markedly wide distal half of the main piece, and from $H$. diazi (Fig. 1) by the rounded apex of the main piece and by the absence of the small dorsal pre-distal $\mathrm{V}$-shaped incision. The aedeagus of $H$. emarginata (Fig. 11) can be distinguished also by its distinctly larger size (PL: 610-665 $\mu \mathrm{m}$ ), and by the distinctly larger distal lobe. Moreover, $H$. fosterorum could be easily distinguished from any other species of the $H$. emarginata-saga complex by the peculiar female elytral shape (Fig. 8).

Distribution: H. fosterorum is known only from the north of the Iberian System mountains, in Sierra de la Demanda and del Moncayo. Specimens from that region previously attributed to $H$. saga (e.g. Valladares et al. 2000) almost certainly belong to the new species.

Etymology: We are pleased to dedicate this species to our friends Sue and Garth Foster, who collected some of the paratypes with IR.

\section{A molecular phylogeny of the H.emarginata-saga clade}

The optimal evolutionary models as selected by jModeltest among those implemented in MrBayes were GTR $+\mathrm{I}+\mathrm{G}$ for the coxl fragment and $\mathrm{HKY}+\mathrm{I}$ for the $r r n L+t r n L+$ nadl fragment. There was no length variation in the protein coding genes, and in the ribosomal gene length variation was reduced to a single nucleotide deletion in the outgroups $(H$. sinope and $H$. septemlacuum), and thus the alignment was trivial.

The Bayesian runs converged at ca. 600,000 generations, with a standard deviation of the split frequencies around 0.01. The 1600 sampled trees were enough to obtain good estimates of all parameters, as established by the effective sample size (measured in Tracer v1.5, Drummond \& Rambaut 2007) and the convergent diagnostics in MrBayes (Huelsenbeck $\&$ Ronquist 2001). The topology (Fig. 12) of the well supported nodes (i.e. Bayesian posterior probability $>0.9$, ML Boostrap $>70 \%$ ) was identical for both methods used, with differences in poorly supported nodes only. The mitochondrial haplotypes of the two eastern specimens of $H$. saga were identical to those of $H$. alpicola from Austria, suggesting a very recent divergence between both species. The western $H$. diazi and $H$. fosterorum were included in a clade with two other Iberian endemics ( $H$. emarginata and $H$. hispanica) with moderate support, but clearly not directly related to the eastern $H$. saga (Fig. 12). The position of $H$. samnitica and H. pangaei, not included in the analyses of Ribera et al. (in press), could not be recovered with good support. Other results fully agree with those obtained by Ribera et al. (in press).

There was no variation among the two sequenced specimens of $H$. fosterorum, which were from close localities in Burgos and Logroño, and only two nucleotides (ca. $0.3 \%$ ) in the coxl of the specimens of $H$. diazi from the Montseny and Guipuzkoa, at both sides of the known distribution of the species. The estimated time divergence between the two species, measured with a mitochondrial rate of $2 \%$ per MY, was 150,000 years, in the late Pleistocene (see Ribera et al. in press for details).

The low genetic divergence between the two newly described species, and their allopatric but geographically contiguous distribution fully agree with the diversification model for some of the species of the "Haenydra" lineage suggested by Ribera et al. (in press). It seems thus likely that the current species of the $H$. emarginata-saga complex are the result of the fragmentation of a common ancestor that expanded its range through the north of the Iberian Peninsula ca. 0.5 MY ago, with the resulting species keeping their original ranges through the speciation process. 


\section{Aknowledgements}

We thank all collectors mentioned in Table 1 for the help with specimens for study, and in particular Sue \& Garth Foster, Carles Hernando and the late Pedro Aguilera for their help in collecting the type series of both new species. We are indebted to Dr. Pierfilippo Cerretti (CNBF, Verona, Italy) for female elytral photographs, and to Dr. Gloria Antonini (University Sapienza, Rome, Italy) for her constant help in laboratory and for valuable comments and suggestions. A visit of the first author to the NMW was supported by Synthesys (Application AT-TAF-53); the work of IR was funded by projects CGL2007-61665 and CGL201015755.

\section{References}

Audisio, P., Trizzino, M., De Biase, A., Mancini, E. \& Antonini, G. (2009) A new species of Hydraena (Coleoptera: Hydraenidae) of the H. evanescens complex from Sardinia. Zootaxa, 2318, 281-289.

Drummond, A. \& Rambaut, A. (2007) Beast: Bayesian evolutionary analysis by sampling trees. BMC Evolutionary Biology, 7, 214.

Huelsenbeck, J.P. \& Ronquist, F. (2001) MrBayes: Bayesian inference of phylogenetic trees. Bioinformatics, 17, 754-755.

Jäch, M.A., Beutel, R.G., Díaz, J.A. \& Kodada, J. (2000) Subgeneric classification, description of head structures, and world check list of Hydraena Kugelann (Insecta: Coleoptera: Hydraenidae). Annalen des Naturhistorischen Museums in Wien, Series B, $102,177-258$.

Jäch, M.A. (2004) Hydraenidae. In: I. Löbl \& A. Smetana (Eds), Catalogue of Palaearctic Coleoptera. Volume 2: Hydrophiloidea - Histeroidea - Staphylinoidea. Apollo Books, pp. 102-122.

Orchymont, A. d' (1930) Nouvelles notes sur quelques Hydraena paléarctiques. Bull. Ann. Soc. Ent. Belg., 70, 218-228.

Posada, D. (2008) JModelTest phylogenetic model averaging. Molecular Biology and Evolution, 25(7), 1253-1256.

Ribera, I., Castro, A., Díaz, J.A., Garrido, J., Izquierdo, A., Jäch, M.A. \& Valladares, L.F. (in press) The geography of speciation in narrow endemics of the "Haenydra" lineage (Coleoptera, Hydraenidae, Hydraena). Journal of biogeography in press.

Stamatakis, A., Hoover, P. \& Rougemont, J. (2008) A rapid bootstrap algorithm for the RAxML web servers. Systematic Biology, 57, 758-771.

Valladares, L.F., Díaz, J.A. \& Garrido, J. (2000) Coleópteros acuáticos del Sistema Ibérico Septentrional (Coleoptera: Haliplidae, Gyrinidae, Dytiscidae, Hydraenidae, Helophoridae, Hydrochidae, Hydrophilidae). Boletín de la Asociación Española de Entomología, 24(3-4), 59-84. 
Table 1 - Specimens used in the molecular study, with locality, collector, voucher reference numbers and accession numbers for the sequences

\begin{tabular}{|c|c|c|c|c|c|c|c|c|}
\hline Species & Voucher & Ref & Country & Locality & Date & Collector & $\operatorname{cox} 1$ & $\begin{array}{r}\text { rrnL+trı } \\
+ \text { nad1 }\end{array}$ \\
\hline alpicola & MNCN-AI483 & 23829 & Austria & $\begin{array}{l}\text { Niederösterreich, Schwarzenbach, road } 18 \mathrm{~W} \\
\text { Sankt Veit an der Gölsen, } 448 \mathrm{~m} \text {, } \\
\text { N48 } 04^{\prime} 42.4^{\prime \prime} \text { E1 } 15^{\circ} 40^{\prime} 42.9^{\prime \prime} .\end{array}$ & 6.8 .05 & $\begin{array}{l}\text { I. Ribera \& A. } \\
\text { Cieslak }\end{array}$ & & \\
\hline alpicola & MNCN-AI347 & 23693 & Austria & $\begin{array}{l}\text { Niederösterreich, Schwarzenbach, road } 18 \mathrm{~W} \\
\text { Sankt Veit an der Gölsen, } 448 \mathrm{~m} \text {, } \\
\text { N48 } 04^{\prime} 42.4^{\prime \prime} \text { E15 } 45^{\circ} 42.9^{\prime \prime} .\end{array}$ & 6.8 .05 & $\begin{array}{l}\text { I. Ribera \& A. } \\
\text { Cieslak }\end{array}$ & HM588354 & HM5884! \\
\hline anatolica & MNCN-AI802 & 24148 & Turkey & $\begin{array}{l}\text { Kastamonu, Road } 759 \text { to Senpazar, Çocukören } \\
\text { Çoyl, fast stream in mixed forest , } 591 \mathrm{~m} \text {, } \\
\text { N41 } 41^{\circ} 38^{\prime \prime} \text { E } 33^{\circ} 25^{\prime} 03^{\prime \prime} \text {. }\end{array}$ & 26.4 .06 & I. Ribera & HM588395 & HM5885: \\
\hline belgica & MNCN-AI426 & 23772 & Austria & $\begin{array}{l}\text { Niederösterreich, Schaubach, ca. } 270 \mathrm{~m}, \\
\text { Schauboden, } 3.5 \mathrm{~km} \text { N. Purgstall, N } 48^{\circ} 05^{\prime} 23^{\prime}, \\
\text { E1508'20'. }\end{array}$ & 25.9.05 & M.A. Jäch & HM588372 & HM5885 \\
\hline diazi & MNCN-AI479 & 23825 & Spain & $\begin{array}{l}\text { Barcelona,, Santa Fe del Montseny, road Turo } \\
\text { del Home, Sot de Bernadal, } 1134 \mathrm{~m} \text {, } \\
\text { N41 } 455^{\prime} 45.2^{\prime \prime} \text { E2 } 26 \text { "55.0". }\end{array}$ & 23.7 .05 & I. Ribera & HM588378 & HM5885: \\
\hline diazi & MNCN-AI1011 & 24357 & Spain & 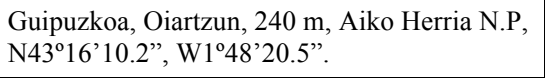 & 16.7.06 & $\begin{array}{l}\text { I. Ribera \& A. } \\
\text { Cieslak }\end{array}$ & & \\
\hline emarginata & MNCN-AI325 & 23671 & Spain & $\begin{array}{l}\text { Lugo, Os Ancares, road LU723., Sierra do } \\
\text { Agulleiro, Donis, Río da Vara, } 1006 \text { m, } \\
\text { N4249'31.2”, W6'52'50.7”. }\end{array}$ & 10.7.05 & $\begin{array}{l}\text { I. Ribera \& A. } \\
\text { Cieslak }\end{array}$ & HM588346 & HM5884! \\
\hline exasperata & MNCN-AI506 & 23852 & Spain & León, Puerto de Panderrueda & 12.7 .05 & L.F. Valladares & HM588382 & HM5885: \\
\hline excisa & MNCN-AI348 & 23694 & Austria & $\begin{array}{l}\text { Niederösterreich, Schwarzenbach, road } 18 \mathrm{~W} \\
\text { Sankt Veit an der Gölsen, } 448 \mathrm{~m} \text {, } \\
\text { N48 } 04^{\prime} 42.4^{\prime \prime}, \text { E15 } 45^{\circ} 42.9^{\prime \prime} .\end{array}$ & 6.8 .05 & $\begin{array}{l}\text { I. Ribera \& A. } \\
\text { Cieslak }\end{array}$ & HM588355 & HM5884! \\
\hline cfr. excisa & MNCN-AI391 & 23737 & Bulgaria & Rila Mts. Stream above Bacevo. $1500 \mathrm{~m}$ & 6.7 .05 & D.T. Bilton & HM588365 & HM58851 \\
\hline fosterorum & MNCN-AI282 & 23628 & Spain & $\begin{array}{l}\text { Burgos, Fresneda de la Sierra, RíoTirón, } 1085 \\
\text { m N42¹6’46.2", W37'56.0”. }\end{array}$ & 22.10 .04 & I. Ribera & & \\
\hline fosterorum & MNCN-AI481 & 23827 & Spain & 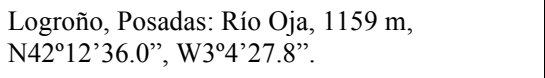 & 23.10 .04 & I. Ribera & HM588379 & HM5885: \\
\hline gracilis & MNCN-AI332 & 23678 & Latvia & Gaujas N.P., stream in forest. & 13.6.05 & D.T. Bilton & HM588348 & HM5884! \\
\hline gracilis & MNCN-AI333 & 23679 & England & Cumbria, river Irthing at Spadeadam Waste & 26.6 .05 & D.T. Bilton & HM588349 & HM5884! \\
\hline gracilis & MNCN-AI338 & 23684 & Bulgaria & $\begin{array}{l}\text { Rhodope Mts., road Goce Delcev to Dospat, } \\
\text { stream, } 1000 \mathrm{~m} .\end{array}$ & 10.7 .05 & D.T. Bilton & HM588350 & HM5884! \\
\hline gracilis & MNCN-AI510 & 23856 & Spain & Cantabria, Beges & 13.7.05 & L.F. Valladares & HM588384 & HM5885: \\
\hline gracilis & MNCN-AI1012 & 24358 & Spain & $\begin{array}{l}\text { Guipuzkoa, Oiartzun, } 240 \mathrm{~m} \text {, Aiko Herria } \\
\text { National Park, N43ำ } 16^{\prime} 10.2^{\prime \prime}, \mathrm{W} 1^{\circ} 48^{\prime} 20.5^{\prime \prime} \text {. }\end{array}$ & 16.7.06 & $\begin{array}{l}\text { I. Ribera \& A. } \\
\text { Cieslak }\end{array}$ & HM588311 & \\
\hline gracilis & MNCN-AI905 & 24251 & Spain & León, Puerto de Panderrueda & 12.7 .05 & L.F. Valladares & HM588398 & \\
\hline hispanica & MNCN-AI329 & 23675 & Spain & $\begin{array}{l}\text { Ourense, Sierra de Queixa, } 2 \mathrm{~km} \mathrm{~S} \\
\text { Manzaneda, tributary of San Lázaro river, } 770 \\
\text { m, N42 } 17^{\prime} 04^{\prime \prime}, \mathrm{W}^{\circ} 13^{\prime} 21.2^{\prime \prime} \text {. }\end{array}$ & 9.7 .05 & $\begin{array}{l}\text { I. Ribera \& A. } \\
\text { Cieslak }\end{array}$ & HM588347 & HM5884! \\
\hline integra & MNCN-AI783 & 24129 & Turkey & $\begin{array}{l}\text { Bolu, road } 750 \text { btw Yeniçaga \& Mengen, fast } \\
\text { stream in mixed forest, } 844 \mathrm{~m}, \mathrm{~N} 40^{\circ} 50^{\prime} 49^{\prime \prime} \text {, } \\
\text { E32 } 03^{\prime} 47.5^{\prime \prime} \text {. }\end{array}$ & 24.4 .06 & I. Ribera & HM588392 & HM5885: \\
\hline larissae & $\mathrm{MNCN}-\mathrm{AI} 303$ & 23649 & Italy & $\begin{array}{l}\text { Lombardia, Brescia, val Trompia, road to } \\
\text { Giogo della Bala, stream, ca. } 1500 \mathrm{~m} \text {. }\end{array}$ & 17.10 .02 & $\begin{array}{l}\text { I. Ribera \& A. } \\
\text { Cieslak }\end{array}$ & HM588340 & HM5884i \\
\hline pangaei & CSR-80_1 & H080_1 & Greece & $\begin{array}{l}\text { Kavala, Pangeon, road to Sky Center, } \\
\text { deviation after } 15 \mathrm{~km} \text {, small spring, } 994 \mathrm{~m} \text {, } \\
\text { N40 } 53^{\prime} 59.5^{\prime \prime}, \mathrm{E} 24^{\circ} 08^{\prime} 01.9^{\prime \prime}\end{array}$ & 9.9 .08 & $\begin{array}{l}\text { M. Trizzino \& } \\
\text { P. Audisio }\end{array}$ & & \\
\hline saga & $\mathrm{MNCN}-\mathrm{AI} 358$ & 23704 & Slovakia & Nizke Tatry Mts., Poltica river & 25.6 .05 & F. Ciampor & & \\
\hline saga & $\mathrm{MNCN}-\mathrm{AI} 485$ & 23831 & Slovakia & Nizke Tatry Mts., Poltica river & 25.6 .05 & F. Ciampor & & \\
\hline samnitica & CSR-78_1 & H078_1 & Italy & $\begin{array}{l}\text { Abruzzo, Teramo, Pietracamela, stream Arno, } \\
1000 \mathrm{~m} .\end{array}$ & 24.7 .08 & M. De Pace & & \\
\hline septemlacuum & MNCN-AI795 & 24141 & Turkey & 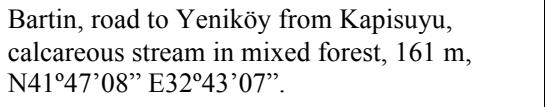 & 25.4.06 & I. Ribera & HM588394 & HM5885: \\
\hline sinope & MNCN-AI788 & 24134 & Turkey & 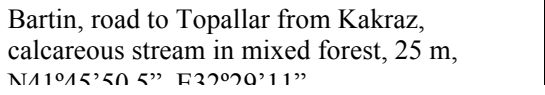 & 25.4 .06 & I. Ribera & HM588393 & HM5885: \\
\hline
\end{tabular}




\section{Figure captions}

Figure 1: Aedeagus in right side view of Hydraena diazi (Spain, Guipuzkoa prov., Oiartzun). Scale bar $=0.2 \mathrm{~mm}$

Figure 2: Female gonocoxite of Hydraena diazi (Spain, Barcelona prov., Santa Fe del Montseny). Scale bar $=0.2 \mathrm{~mm}$.

Figure 3: Female tergite X of Hydraena diazi (Spain, Barcelona prov., Santa Fe del Montseny). Scale bar $=0.2 \mathrm{~mm}$.

Figure 4: Female elytral apices (not scaled) of Hydraena diazi (Spain, Barcelona prov., Santa Fe del Montseny).

Figure 5: Aedeagus in right side view of Hydraena fosterorum (Spain, Burgos prov., Fresneda de la Sierra). Scale bar $=0.2 \mathrm{~mm}$.

Figure 6: Female gonocoxite of Hydraena fosterorum (Spain, Burgos prov., Fresneda de la Sierra). Scale bar $=0.2 \mathrm{~mm}$.

Figure 7: Female tergite X of Hydraena fosterorum (Spain, Burgos prov., Fresneda de la Sierra). Scale bar $=0.2 \mathrm{~mm}$.

Figure 8: Female elytral apices (not scaled) of Hydraena fosterorum (Spain, Burgos prov., Fresneda de la Sierra).

Figure 9: Aedeagus in right side view of Hydraena saga (Slovakia, Muran), distal lobe omitted. Scale bar $=0.2 \mathrm{~mm}$.

Figure 10: Aedeagus in right side view of Hydraena alpicola (Slovenia, Valdekom). Scale bar $=0.2 \mathrm{~mm}$.

Figure 11: Aedeagus in right side view of Hydraena emarginata (Spain, Leon, Puerto San Isidro). Scale bar $=0.2 \mathrm{~mm}$.

Figure 12: Phylogram of the species of the H. gracilis lineage obtained with RAxML. Numbers at nodes represent Bootstrap support values in RAxML / Bayesian posterior probabilities (only if $>70 \%$ and 0.7 respectively). 


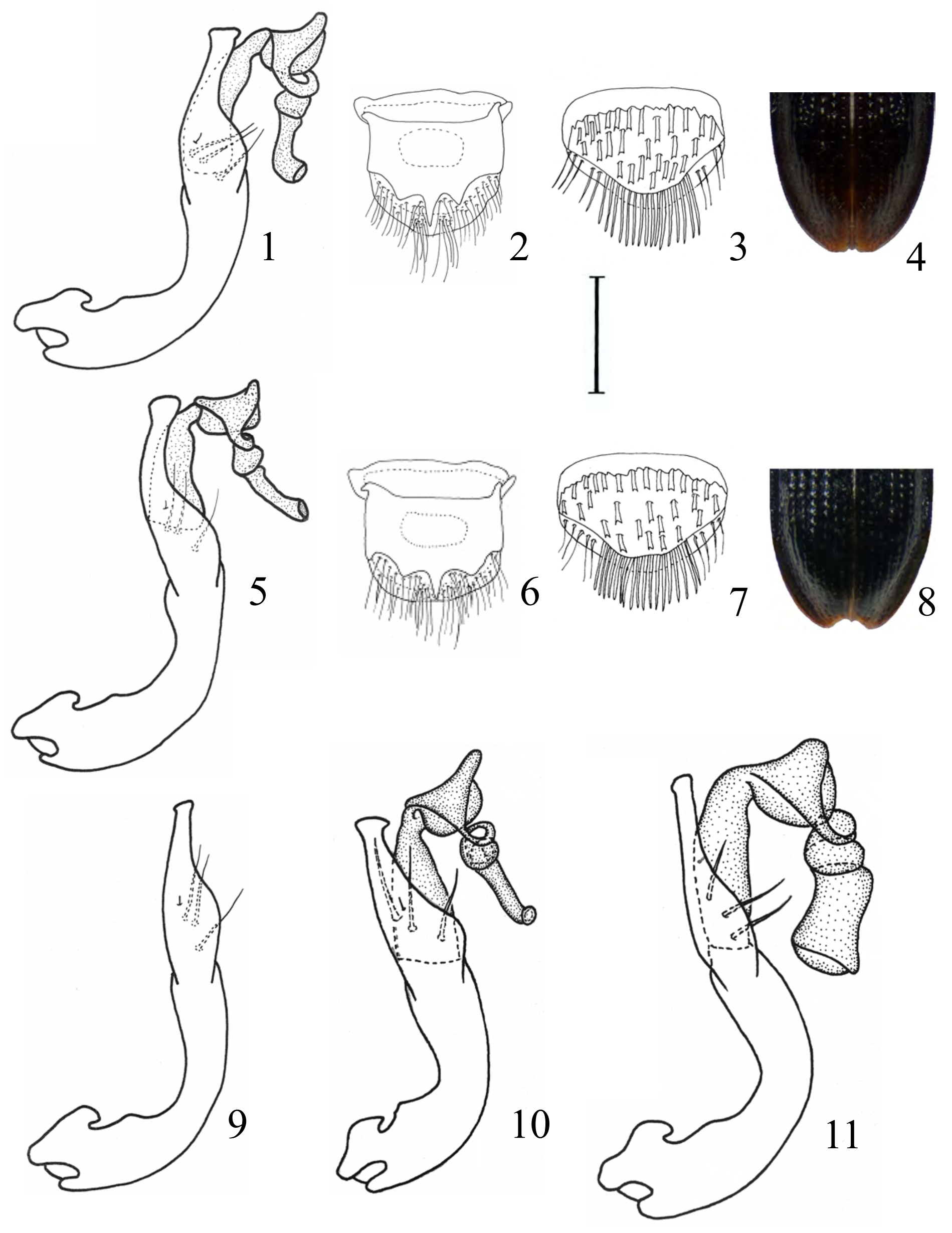


- H. larissae Al303

$81 / 0.71$ H. tarvisina Al967 H. samnitica 78

H. pangaei 80

H. belgica Al426

H. integra Al783

H. dalmatina Al391

H. exasperata Al506

H. saga Al358

H. alpicola Al483

H. saga Al485

$\underbrace{\text { H. gracilis Al1012 }}_{90 / 95} \begin{aligned} & \text { H. gracilis Al510 } \\ & \text { H. gracilis Al905 }\end{aligned}$ 


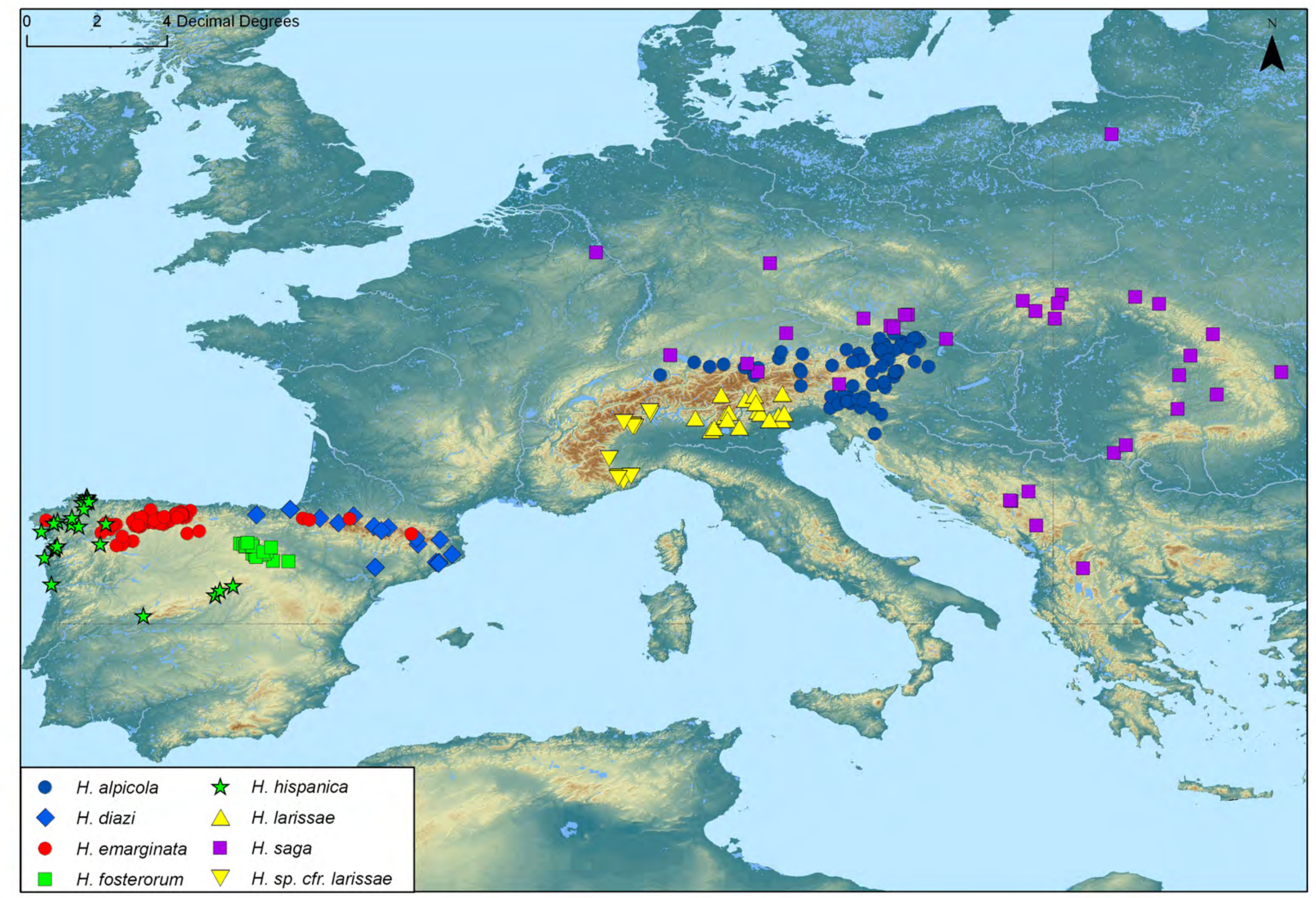

